\title{
An Innovative Training Program for Community Health Workers to Support Engagement of Racial and Ethnic Minorities in Genomics Research and Clinical Programs: a Protocol for the Development of the PREFER (PaRtnEring to build understanding oF gEnomics Responsibly) Training Program
}

Caitlin G. Allen ( $\sim$ allencat@musc.edu )

Research Article

Keywords:

Posted Date: February 4th, 2022

DOI: https://doi.org/10.21203/rs.3.rs-1324745/v1

License: (c) (i) This work is licensed under a Creative Commons Attribution 4.0 International License. Read Full License 


\section{Abstract}

Community health workers (CHWs) are trusted members of communities who have well-established relationships with individuals and families, especially among underserved populations. Prior research highlights interest among CHWs in learning about complex topics related to genetics, especially as public awareness is being raised about hereditary conditions. However, to date, there have been limited efforts to train CHWs on these topics of systematically involve this workforce in research related to genetics and genomics applications. To overcome this gap in training opportunities, we will develop a training specifically designed for CHWs to build competencies in genomics, hereditary conditions, and precision health approaches. The PREFER (PaRtnEring to build understanding oF gEnomics Responsibly) training will follow a Delphi process to gather expert feedback and use social cognitive theory and adult learning theory to guide the course content. In this protocol, we outline the planned approach for the development of the PREFER training program components, evaluation outcomes, and delivery plans.

\section{Background}

Approximately $1-2 \%$ of the US population have a hereditary condition that greatly increases their risk developing serious but preventable diseases. ${ }^{1-4}$ If identified early, there are a number of well-established interventions available to reduce morbidity and mortality of individuals with these conditions. ${ }^{5}$ Partnering with groups that span service settings can help enhance our ability to identify individuals who are highrisk and anticipate and mitigate disparities in hereditary conditions. ${ }^{6}$ Community health workers (CHWs) are a viable group to engage in efforts to improve public understanding of genomics and support early identification of hereditary conditions, especially among minority populations. ${ }^{7} \mathrm{CHWs}$ have expressed high levels of interest in learning about and incorporating genetic information; however, there are few accessible training opportunities for $\mathrm{CHWs} .{ }^{8,9}$ We found that $\mathrm{CHWs}$ seek training that can be integrated into existing workflows and that includes resources to support communicating complex topics with their clients.

To help advance opportunities for $\mathrm{CHWs}$ to engage with community members in complex topics related to genomics, we will use a Delphi Process to develop the PREFER training and establish an evaluation plan to assess outcomes related to $\mathrm{CHW}$ competencies and the quality of the training delivered.

\section{Methods}

Step 1: Delphi Process. We will use a three-round Delphi process to create the PREFER training. Based on a review of current training topics for $\mathrm{CHWs}$ in this area, we have developed a set of topics for the PREFER course. We will develop a prototype for the CHW Curriculum Committee to review (Table 1). The PREFER training uses the social cognitive theory (SCT) to guide the determinants that CHWs need to achieve to support patients in genomics. According to SCT, individuals are more likely to adopt a new behavior if they have a sense of self-efficacy, gain knowledge and skills to overcome obstacles, and have positive expectations about adopting the new behavior. ${ }^{10}$ Thus, the training is designed to increase 
knowledge, skills, and self-efficacy for CHWs to have discussions about hereditary conditions and genomics with their communities. The program will incorporate Adult Learning Theory methods throughout to ensure practical applications of the topics for CHWs. These include: learning should capitalize on the participants' experience, learning should be adapted to the limitations of the participant, adults should be challenged to move to advance stages of personal development, adults should have a choice in organizing the learning program. ${ }^{11}$

Table 1

Topics for Inclusion in PREFER Training

Topic Description

Importance of family history $(1$ hour)

Genetics 101 (1 hour)

Tier 1 conditions ( 1 hour)

Genetic counseling and testing (30 minutes)

Ethical, Legal and Social Issues (1 hour)

Navigating genetic resources (1 hour)

Communication about hereditary conditions (1 hour)
Introduce family history, sharing personal story of someone who tested positive, group discussion with question and answers

Basic concepts of genetics

Practice drawing family histories, case examples and role play, practice drawing family histories in pairs, learn about referrals for affected and unaffected family members

Introduce topic of genetic testing, navigation of genetic testing and counseling services

Discuss ethical, legal and social issues including communicating about family history and potential stigma of passing along deleterious mutation, sharing results, cost of testing, confidentiality

Describe different types of genetic services, group discussion about genetic counseling, demonstrate how to navigate national database of genetic resources

Group discussion about how to apply information discussed to day-to-day work, including motivational interviewing

Curriculum is based on Adult Learning Theory which focuses on sharing personal experiences, learning being adapted to limitations of participants, learners being challenged to move to advanced stages of personal development and having a choice in organizing the learning program. Examples include: scripted role play, group discussion, link to previous knowledge, and case examples.

The three-round Delphi process will follow the RAND/UCLA Appropriateness Method (RAM) for conducting expert panels with the Delphi method, we will include two rounds of rating with a round of discussion between the two rounds. ${ }^{12}$ Round 1: Assessment Round. The expert panel will be instructed to review the curriculum prototype and rate and comment on its different aspects using a 5-point Likert scale; participants will also provide qualitative feedback. Round 2: Feedback and Discussion Round. Experts will receive a personalized report showing how their individual responses to the rating questions compare to the responses of other participants. The report will include a distribution of all responses, a group median response and its interquartile range, and a statement that explains whether the group 
reached agreement. The report will also include a summary of participant's qualitative comments during Round 1. In Round 2, participants will discuss the results of Round 1 using an anonymous, asynchronous threaded discussion board hosted on a learning management platform. We will use randomly generated usernames such as Expert01. We anticipate that this discussion will focus on areas where there may be disagreement or potential confusion. Round 3: Reassessment Round. After the discussion round is complete, we will provide experts with the opportunity to revise their Round 1 answers based on Round 2 feedback and discussion or leave them unchanged. Any modifications made to Round 1 questions will be clearly identified at the end of Round 3. Each round will be open for 7-10 days. Participants will receive an invitation email at the start of each round that will include a description of what they are expected to do, how to access the learning management platform, and how long each round will be open. We will send up to three reminders during each round to encourage all participants provide their input. Upon completing the Delphi process, we will update the curriculum and prepare for delivery.

Measures for Delphi Process. We will use the Kirkpatrick Model of Training Evaluation to develop questions for the Delphi process (Table 2). Participants will be asked to review the PREFER curriculum and rate their level of agreement with each statement using a 5-point Likert agreement scale (strongly disagree to strongly agree) as part of Round 1 and during Round 3. Qualitative assessment questions will be used to help explain the quantitative ratings and be provided to experts as part of Round 2 (feedback and discussion). 
Table 2

Measures used during the Delphi Process

\begin{tabular}{|c|c|c|}
\hline $\begin{array}{l}\text { Kirkpatrick } \\
\text { Model }\end{array}$ & Quantitative Assessment & Qualitative Assessment \\
\hline \multirow[t]{3}{*}{$\begin{array}{l}\text { Reaction: } \\
\text { experience with } \\
\text { the training }\end{array}$} & $\begin{array}{l}\text { - Course materials are } \\
\text { aligned with adult learning } \\
\text { theory }\end{array}$ & $\begin{array}{l}\text { How can we improve participant's response to the } \\
\text { training? }\end{array}$ \\
\hline & $\begin{array}{l}\text { - The length of training is } \\
\text { appropriate for materials } \\
\text { covered }\end{array}$ & \\
\hline & $\begin{array}{l}\text { - The materials are } \\
\text { presented in a way that is } \\
\text { accessible to CHWs }\end{array}$ & \\
\hline \multirow[t]{4}{*}{$\begin{array}{l}\text { Learning: what } \\
\text { was learned as } \\
\text { part of the } \\
\text { training }\end{array}$} & $\begin{array}{l}\text { - Participants learn the } \\
\text { desired knowledge about } \\
\text { genetics and genomics }\end{array}$ & $\begin{array}{l}\text { How much do you think participants will learn from } \\
\text { the training? How will their skills improve? How } \\
\text { can we improve the learning opportunities? }\end{array}$ \\
\hline & $\begin{array}{l}\text { - Participants learn the } \\
\text { desired skills related to } \\
\text { hereditary conditions }\end{array}$ & \\
\hline & $\begin{array}{l}\text { - There is clear integration } \\
\text { of topics }\end{array}$ & \\
\hline & $\begin{array}{l}\text { - Sequencing of topics are } \\
\text { appropriate }\end{array}$ & \\
\hline \multirow[t]{2}{*}{$\begin{array}{l}\text { Behavior. } \\
\text { changes in } \\
\text { behavior } \\
\text { following } \\
\text { training }\end{array}$} & $\begin{array}{l}\text { - Course will help } \mathrm{CHWs} \\
\text { identify individuals at high } \\
\text { risk of hereditary } \\
\text { conditions }\end{array}$ & $\begin{array}{l}\text { How do you see participant's applying their } \\
\text { learning in practice? }\end{array}$ \\
\hline & $\begin{array}{l}\text { - The course content is } \\
\text { relevant to CHW practice }\end{array}$ & \\
\hline \multirow[t]{2}{*}{$\begin{array}{l}\text { Results: longer- } \\
\text { term impact of } \\
\text { training }\end{array}$} & $\begin{array}{l}\text { - Will this empower CHWs } \\
\text { to help change client's } \\
\text { behavior? }\end{array}$ & $\begin{array}{l}\text { Are there ways to enhance the impact of this } \\
\text { training? }\end{array}$ \\
\hline & $\begin{array}{l}\text { - Will this empower } \mathrm{CHWs} \\
\text { to change their behavior? }\end{array}$ & \\
\hline
\end{tabular}

Analysis for Delphi Process. We will use descriptive statistics to present results of Round 1 and 3 ratings for each panel separately, focusing on the frequency distributions of responses to each question, as well as measures of central tendency (median) and dispersion (interpercentile range). Explicit assessment of inter-rater agreement will be performed using kappa coefficients. Significance of these coefficients will be assessed using threshold assessment. To assess patterns of agreement, we will extend this analysis to 
log linear models for multiple categories. Power assessment for these models follows from the log linear formulation.

Delivery and Evaluation of PREFER Training. After finalizing the curriculum, we will deliver and evaluate the training among a cohort of $30 \mathrm{CHWs}$ nationally. $\mathrm{CHWs}$ will be eligible if they are employed by or volunteer for an organization, clinic, institution, hospital or agency providing direct education, outreach or health services to minority populations Specific recruitment strategies include: email outreach, distribution through relevant list servs, and word of mouth. Interested trainees will submit an online application including information about educational and professional background, workplace setting and demographics of the patient and community populations they serve, current educational and referral practices related to genomics, two personal and professional goals for the training, and assurance they can attend all components of the training.

All materials will be delivered virtually using the Zoom platform. Participants will receive a pre-course survey delivered through REDCap two days prior to beginning the course to assess initial knowledge, skills, and self-efficacy in key topics. Participants will also receive a post-course survey immediately following all training to assess change in competencies as well as an evaluation of participant experience with the course. Finally, participants will receive a 6-month after follow-up survey to determine change/attrition in competencies, as well as how the skills gained in this curriculum are being used.

Measures for Course Delivery. Measures are guided by the RE-AIM AIM (Reach, Effectiveness, Adoption, Implementation, and Maintenance) framework to evaluate the course, demonstrate its effectiveness, and gather data prior to future delivery. ${ }^{13,14}$ This organizing framework helps identify the essential program elements that can improve the adoption and implementation of programs (see Table 3). Data sources will include: course records, quantitative surveys delivered pre-course, immediately post-course, and 6-months following the training. 
Table 2

Measures to Assess PREFER CHW Training

\begin{tabular}{|c|c|c|}
\hline RE-AlM Construct & Measures & Source \\
\hline \multirow{5}{*}{$\begin{array}{l}\text { Reach into the target } \\
\text { population. How can we } \\
\text { improve the reach of } \\
\text { PREFER? }\end{array}$} & & \multirow{2}{*}{$\begin{array}{l}\text { Course } \\
\text { records }\end{array}$} \\
\hline & - \% of participants who completed the course & \\
\hline & - \# of people on wait list & \multirow{3}{*}{$\begin{array}{l}\text { Tracking } \\
\text { logs }\end{array}$} \\
\hline & $\begin{array}{l}\text { - Log of recruitment strategies (list servs, types of } \\
\text { outreach) }\end{array}$ & \\
\hline & - Log of questions from potential participants (FAQ) & \\
\hline \multirow{3}{*}{$\begin{array}{l}\text { Effectiveness of the } \\
\text { intervention on } \\
\text { participant knowledge. } \\
\text { Did PREFER improve } \\
\text { trainee's competence in } \\
\text { key learning objectives? }\end{array}$} & $\begin{array}{l}\text { - Genetic health literacy: use REAL-G which captures } \\
\text { functional genetic literacy through key word familiarity and } \\
\text { comprehension measures }{ }^{15}\end{array}$ & $\begin{array}{l}\text { Pre-course } \\
\text { survey }\end{array}$ \\
\hline & $\begin{array}{l}\text { - Genetic knowledge: 8-item multiple choice questionnaire } \\
\text { on general genetic knowledge. }{ }^{15}\end{array}$ & $\begin{array}{l}\text { Immediate } \\
\text { post- } \\
\text { course } \\
\text { survey }\end{array}$ \\
\hline & & $\begin{array}{l}\text { Six-month } \\
\text { post- } \\
\text { course } \\
\text { survey }\end{array}$ \\
\hline \multirow{4}{*}{$\begin{array}{l}\text { Adoption of intervention } \\
\text { components into CHW } \\
\text { practice. How confident } \\
\text { are trainees in using } \\
\text { approaches taught in } \\
\text { the program? }\end{array}$} & $\begin{array}{l}\text { - Self-efficacy for identifying at risk women, providing } \\
\text { education, referral, and navigation services as assessed } \\
\text { with items adapted from scales of self-efficacy for genetic }\end{array}$ & $\begin{array}{l}\text { Pre-course } \\
\text { survey }\end{array}$ \\
\hline & $\begin{array}{l}\text { counseling. } 7 \text { item measure assesses on 10-point Likert } \\
\text { scale and summed }\end{array}$ & \multirow{2}{*}{$\begin{array}{l}\text { Immediate } \\
\text { post- } \\
\text { course } \\
\text { survey }\end{array}$} \\
\hline & - Attitudes toward genetic counseling and testing: 17 item & \\
\hline & $\begin{array}{l}\text { benefits for genetic testing for cancer and } 9 \text { items } \\
\text { assessed perceived barriers to genetic testing for cancer } \\
\text { risk, and } 5 \text { items assessed concerns related to genetic } \\
\text { counseling and testing }{ }^{17}\end{array}$ & $\begin{array}{l}\text { Six-month } \\
\text { post- } \\
\text { course } \\
\text { survey }\end{array}$ \\
\hline \multirow[t]{3}{*}{$\begin{array}{l}\text { Implementation of } \\
\text { training. How well was } \\
\text { PREFER implemented? }\end{array}$} & $\begin{array}{l}\text { - Kirkpatrick Model Measures to assess reaction, learning, } \\
\text { behavior and results (e.g., training objectives were clearly } \\
\text { articulated, information presented in an understandable } \\
\text { way, provided personal value). Measured on 5-point Likert } \\
\text { scale. }^{18}\end{array}$ & \multirow[t]{3}{*}{$\begin{array}{l}\text { Immediate } \\
\text { post- } \\
\text { course } \\
\text { survey }\end{array}$} \\
\hline & - Rank order of preferred learning sessions & \\
\hline & $\begin{array}{l}\text { - Open ended questions about the aspects of training } \\
\text { sessions that were most helpful, least helpful, and how } \\
\text { they intended to use the information within community }\end{array}$ & \\
\hline
\end{tabular}




\begin{tabular}{|lll|}
\hline RE-AIM Construct & Measures & Source \\
\hline $\begin{array}{l}\text { Maintenance of effects } \\
\text { of program over time. Do }\end{array}$ & - Participant log of number of: \# of people discussed & Immediate \\
trainees retain & genetics, \# identified, referred, or navigated at high-risk for & post- \\
knowledge learned from & genetic services ${ }^{19,20}$ & course \\
PREFER? & survey \\
& - Perceived relevance of training: Agreement with & Six-month \\
& Statement: "This training is relevant to my work as a CHW." & $\begin{array}{l}\text { Sixt- } \\
\text { Measured on 5-point Likert scale. }\end{array}$ \\
& & course \\
& & survey \\
\hline
\end{tabular}

Analysis for PREFER Training. For individual question responses we will assume a categorial logistic model and employ item response theory (IRT) to assess the latent responses underlying the data. These will be longitudinal in form and we plan to test hypotheses focused on a) differences between different time points for individual questions, b) common across-participant groupings on the longitudinal responses. For groups of questions, we will assume a multivariate logistic longitudinal modeling framework whereby we will assess both inter participant and inter-question group latent groupings. In terms of power and sample size we assume a logistic linear model with fixed correlation over time. For power of 0.815 and alpha level of .05 we can achieve a two-period regression (trend) effect of 0.33 , assuming and intercept of -0.5 and adjusted predictor of 0.2 , based on a simulation of 1000 samples of size 100 . For a sample size of 30 with power 0.548 and adjusted predictor of 0.3 , the achievable effect size is 0.5 . Drop out from the study will be examined and we plan to use intention to treat (ITT) so that all data arising will be considered, with missing data imputed where appropriate. For non-random missingness we will assume a survival model for the drop-out mechanism.

\section{Description}

Our goal is to develop, and pilot test an accessible, relevant training to support CHWs in building competencies related to genetics and genomics. We use an iterative approach that engages multiple stakeholders in support the curriculum design. The Delphi method will allow for initial feedback, with ongoing assessment of content during initial program delivery to a national cohort of CHWs. By tracking impact of the training over time, we will be able to assess the effectiveness of this program and its influence on both $\mathrm{CHW}$ behaviors and client behaviors. This course will offer a flexible approach to engage $\mathrm{CHWs}$ in essential topics, with the opportunity to modify and adapt course modules as genomics research continue to evolve.

\section{Declarations}

Competing interests: The authors declare no competing interests.

\section{References}


1. Manickam K, Buchanan AH, Schwartz MLB, et al. Exome Sequencing-Based Screening for BRCA1/2 Expected Pathogenic Variants Among Adult Biobank Participants. JAMA Netw Open. Sep 7 2018;1(5):e182140. doi:10.1001/jamanetworkopen.2018.2140

2. Saadatagah S, Jose M, Dikilitas 0 , et al. Genetic basis of hypercholesterolemia in adults. NPJ Genom Med. 2021;6(1):28-28. doi:10.1038/s41525-021-00190-z

3. Win AK, Jenkins MA, Dowty JG, et al. Prevalence and Penetrance of Major Genes and Polygenes for Colorectal Cancer. Cancer epidemiology, biomarkers \& prevention: a publication of the American Association for Cancer Research, cosponsored by the American Society of Preventive Oncology. Mar 2017;26(3):404-412. doi:10.1158/1055-9965.Epi-16-0693

4. Austin MA, Hutter CM, Zimmern RL, Humphries SE. Genetic causes of monogenic heterozygous familial hypercholesterolemia: a HuGE prevalence review. American journal of epidemiology. Sep 1 2004;160(5):407-20. doi:10.1093/aje/kwh236

5. Centers for Disease Control and Prevention. Tier 1 Genomics Applications and their Importance to Public Health. https://www.cdc.gov/genomics/implementation/toolkit/tier1.htm

6. Senier L, McBride CM, Ramsey AT, Bonham VL, Chambers DA. Blending Insights from Implementation Science and the Social Sciences to Mitigate Inequities in Screening for Hereditary Cancer Syndromes. Int J Environ Res Public Health. Oct 15 2019;16(20)doi:10.3390/ijerph16203899

7. Allen CG, McBride CM, Balcazar HG, Kaphingst KA. Community Health Workers: An Untapped Resource to Promote Genomic Literacy. Journal of health communication. 2016;21(sup2):25-29. doi:10.1080/10810730.2016.1196272

8. Allen CG, Bethea BJ, McKinney LP, et al. Exploring the Role of Community Health Workers in Improving the Collection of Family Health History: A Pilot Study. Health promotion practice. May 28 2021:15248399211019980. doi:10.1177/15248399211019980

9. Chen LS, Kim M. Needs assessment in genomic education: a survey of health educators in the United States. Health promotion practice. Jul 2014;15(4):592-8. doi:10.1177/1524839913483470

10. Bandura A. Health promotion by social cognitive means. Health education \& behavior: the official publication of the Society for Public Health Education. Apr 2004;31(2):143-64.

doi:10.1177/1090198104263660

11. Kemple T. Adult learning theory. The British journal of general practice: the journal of the Royal College of General Practitioners. Mar 2000;50(452):238.

12. The RAND Corporation. The RAND/UCLA Appropriateness Method User's Manual. https://www.rand.org/pubs/monograph_reports/MR1269.html

13. Glasgow RE, Klesges LM, Dzewaltowski DA, Estabrooks PA, Vogt TM. Evaluating the impact of health promotion programs: using the RE-AIM framework to form summary measures for decision making involving complex issues. Health education research. Oct 2006;21(5):688-94. doi:10.1093/her/cyl081

14. Glasgow RE, Vogt TM, Boles SM. Evaluating the public health impact of health promotion interventions: the RE-AIM framework. American journal of public health. Sep 1999;89(9):1322-7. 
15. Rodríguez SA, Roter DL, Castillo-Salgado C, Hooker GW, Erby LH. Translation and validation of a Spanish-language genetic health literacy screening tool. Health Psychol. Feb 2015;34(2):120-9. doi:10.1037/hea0000162

16. Rivera YM, Moreno L, Briant KJ, et al. Developing Sustainable Cancer Education Programs: Training Public Health Students to Deliver Cancer 101 in Puerto Rico. Journal of cancer education: the official journal of the American Association for Cancer Education. 2018;33(1):128-133.

doi:10.1007/s13187-016-1076-4

17. Sussner KM, Thompson HS, Valdimarsdottir HB, Redd WH, Jandorf L. Acculturation and familiarity with, attitudes towards and beliefs about genetic testing for cancer risk within Latinas in East Harlem, New York City. Journal of genetic counseling. Feb 2009;18(1):60-71. doi:10.1007/s10897008-9182-z

18. Kirkpatrick BE, Rashkin MD. Ancestry Testing and the Practice of Genetic Counseling. Journal of genetic counseling. Feb 2017;26(1):6-20. doi:10.1007/s10897-016-0014-2

19. Rush CL, Darling M, Elliott MG, et al. Engaging Latina cancer survivors, their caregivers, and community partners in a randomized controlled trial: Nueva Vida intervention. Qual Life Res. May 2015;24(5):1107-18. doi:10.1007/s11136-014-0847-9

20. Vadaparampil ST, Hutchins NM, Quinn GP. Reproductive health in the adolescent and young adult cancer patient: an innovative training program for oncology nurses. Journal of cancer education: the official journal of the American Association for Cancer Education. Mar 2013;28(1):197-208. doi:10.1007/s13187-012-0435-z 